OPEN ACCESS

Edited by:

Mariusz Cycon

Medical University of Silesia, Poland

Reviewed by:

Ademir Araujo,

Federal University of Piauí, Brazil

Mazhar Rafique,

Çukurova University, Turkey

Christel Baum,

University of Rostock, Germany

${ }^{*}$ Correspondence:

Xiumei Yu

yuxiumeicoo/@163.com

†These authors have contributed equally to this work

Specialty section:

This article was submitted to Microbiotechnology, Ecotoxicology and Bioremediation,

a section of the journal

Frontiers in Microbiology

Received: 29 March 2018

Accepted: 24 July 2018

Published: 27 August 2018

Citation:

Kang X, Yu X, Zhang Y, Cui Y, Tu W, Wang Q, Li Y, Hu L, Gu Y, Zhao K,

Xiang $Q$, Chen $Q$, Ma M, Zou L,

Zhang X and Kang J (2018) Inoculation of Sinorhizobium saheli YH1 Leads to Reduced Metal Uptake for Leucaena leucocephala Grown in Mine Tailings and Metal-Polluted Soils.

Front. Microbiol. 9:1853.

doi: 10.3389/fmicb.2018.01853

\section{Inoculation of Sinorhizobium saheli YH1 Leads to Reduced Metal Uptake for Leucaena leucocephala Grown in Mine Tailings and Metal-Polluted Soils}

Xia Kang ${ }^{1,2 t}$, Xiumei Yu ${ }^{1 * t}$, Yu Zhang ${ }^{1}$, Yongliang Cui ${ }^{3}$, Weiguo $T u^{3}$, Qiongyao Wang ${ }^{3}$, Yanmei $\mathrm{Li}^{1}$, Lanfang $\mathrm{Hu}^{1}$, Yunfu $\mathrm{Gu}^{1}$, Ke Zhao ${ }^{1}$, Quanju Xiang ${ }^{1}$, Qiang Chen ${ }^{1}$, Menggen Ma ${ }^{1}$, Likou Zou ${ }^{1}$, Xiaoping Zhang ${ }^{1}$ and Jinsan Kang ${ }^{4}$

${ }^{1}$ College of Resources, Sichuan Agricultural University, Chengdu, China, ${ }^{2}$ Geomicrobiology Group, School of Life Sciences, University of Dundee, Dundee, United Kingdom, ${ }^{3}$ Sichuan Provincial Academy of Natural Resource and Sciences, Chengdu, China, ${ }^{4}$ Sichuan Earthquake Administration, Chengdu, China

Metalliferous mine tailings have a negative impact on the soil environment near mining areas and render cultivable lands infertile. Phytoremediation involving the synergism of legume and rhizobia provides a useful technique in tackling this issue with cost-effective, environmentally friendly, and easy-to-use features under adverse soil conditions. Leucaena leucocephala has been found to build symbiotic relationships with native rhizobia in the iron-vanadium-titanium oxide ( $\mathrm{V}$-Ti magnetite) mine tailing soil. Rhizobia $Y H 1$, isolated from the root nodules of $L$. leucocephala, was classified as Sinorhizobium saheli according to similarity and phylogenetic analyses of $16 \mathrm{~S}$ rRNA, housekeeping and nitrogen fixation genes. Besides nitrogen fixation, S. saheli YH1 also showed capabilities to produce indole-acetic acid (IAA) (166.77 $\left.\pm 2.03 \mathrm{mg} \mathrm{I}^{-1}\right)$ and solubilize phosphate $\left(104.41 \pm 7.48 \mathrm{mg} \mathrm{I}^{-1}\right)$. Pot culture experiments showed that strain $\mathrm{YH} 1$ increased the biomass, plant height and root length of $L$. leucocephala by $67.2,39.5$ and $27.2 \%$ respectively. There was also an average increase in plant $\mathrm{N}(10.0 \%), \mathrm{P}(112.2 \%)$ and $\mathrm{K}$ (25.0\%) contents compared to inoculation-free control. The inoculation of $\mathrm{YH} 1$ not only reduced the uptake of all metals by $L$. leucocephala in the mine tailings, but also resulted in decreased uptake of $\mathrm{Cd}$ by up to $79.9 \%$ and $\mathrm{Mn}$ by up to $67.6 \%$ for plants grown in soils contaminated with $\mathrm{Cd} / \mathrm{Mn}$. It was concluded that $\mathrm{S}$. saheli $\mathrm{YH} 1$ possessed multiple beneficial effects on $L$. leucocephala grown in metalliferous soils. Our findings highlight the role of $S$. saheli $\mathrm{YH} 1$ in improving plant health of $L$. leucocephala by reducing metal uptake by plants grown in heavy metal-polluted soils. We also suggest the idea of using L. leucocephala-S. saheli association for phytoremediation and revegetation of $\mathrm{V}$-Ti mine tailings and soils polluted with $\mathrm{Cd}$ or $\mathrm{Mn}$.

Keywords: mine tailings, heavy metals, Leucaena leucocephala, Sinorhizobium, phytoremediation 


\section{INTRODUCTION}

Industrial activities, e.g., mining and smelting, are a major source of water and soil pollutions and threaten human health through accumulative effects along food chains (Wuana and Okieimen, 2011). Residents living in proximity to mining areas are continually exposed to hazardous substances released from the factories. Large swathes of cultivable land have been laid to waste as a result of mine tailings being continuously dumped in huge volumes into reservoir-like ponds. Chronic damages to the surrounding soil environment are caused through leaching effects by rainfall. Vanadium-titanium ( $\mathrm{V}-\mathrm{Ti})$ magnetite mine tailings contain elevated amounts $\left(>2,000 \mathrm{mg} \mathrm{kg}^{-1}\right)$ of manganese (Yu et al., 2014), which is considered to be a major metal pollutant in soil and aquatic environments ( $\mathrm{Li}$ et al., 2014). Cadmium is one of the main heavy metal pollutants that have high cytotoxicity and usually associate with anthropogenic activities such as mining and metal smelting, causing severe contamination to agricultural soils near the vicinity of mines (Liu et al., 2013; Zheng et al., 2018). It is necessary to give a satisfactory solution to this environmental hazard.

Plant growth-promoting rhizobacteria (PGPR) are noted for their capabilities to colonize roots of legumes and at the same time confer beneficial effects on the hosts by alleviating deleterious abiotic stresses (Rajkumar et al., 2010). They have been deemed as a promising approach to the remediation of polluted soils for the rhizobia-legume associations not only promote plant growth but also raise soil nitrogen level, leading to an increased crop yield (Bashan and Holguin, 1998). Several rhizobial species that can form mutualism with legumes are primarily found in genera Azorhizobium, Bradyrhizobium, Mesorhizobium, Rhizobium, and Sinorhizobium (Hayat et al., 2010). Symbiotic nitrogen fixers in the rhizosphere colonize root systems through sophisticated mechanisms at both cellular and molecular levels. Legume-rhizobia associations can lead to enhanced plant growth either by biological nitrogen fixation (Sanginga et al., 1988), indole-3-acetic acid (IAA) production, siderophore secretion, and phosphorus solubilization or by a combination of all the above mentioned features (Khan et al., 2009). It was reported that the symbiosis of Sinorhizobium meliloti CCNWSX0020 and Medicago lupulina exhibited phytostabilizing effects for $\mathrm{Cu}$ by boosting plant growth and metal uptake from $\mathrm{Cu}$-spiked soil while decreasing the translocation of $\mathrm{Cu}$ in the plant (Kong et al., 2015). In another report, the biofuel legume Pongamia pinnata was used for the phytoremediation of V-Ti magnetite mine tailings in partnership with Bradyrhizobium liaoningense and both plant growth and metal uptake were significantly increased under multi-metallic conditions (Yu et al., 2016).

Leucaena leucocephala first came under notice due to its water holding capacity in a hot and dry climate. Besides, it has strong tolerance and adaptability to drought and therefore is of great importance for agriculture and forestry (Shelton and Brewbaker, 1998). L. leucocephala was introduced to Panzhihua city, a major industrial hub in southern Sichuan Province 30 years ago as a pioneer species for afforestation and has ever since been widely cultivated along the hot and arid valleys of Golden Sand River, upper Yangtze (Xu et al., 2013a). A previous study found that it could serve as a pioneer for the revegetation of lead-zinc and tin mine tailings, indicating its potential to thrive under metal-contaminated environments (Li, 2006). In another case, a variant of $L$. leucocephala was discovered to be capable of taking up and metabolizing organic pollutants such as ethylene dibromide and trichloroethylene even without the synergism of rhizobia, which again proves that it could be a potential candidate for the remediation of polluted soils (Doty et al., 2003). Although many other similar studies for the remediation of heavy metal-contaminated sites have been reported of late years, the information on remediation effects of $L$. leucocephala and its associated rhizobia is still scanty.

In the present study, we aim to establish the rhizobiaplant association and explore the feasibility of using it as a novel means for the phytoremediation and revegetation of heavy metal-polluted soils. In this work, we report PGP effects of Sinorhizobium saheli YH1 on and reduced metal uptake for L. leucocephala in the phytoremediation of both original mine tailings and soils supplemented with $\mathrm{Cd}$ or Mn. Our results propound the idea of utilizing the symbiotic system of L. leucocephala and S. saheli $\mathrm{YH} 1$ as an alternative to the alleviation of environmental hazards including $\mathrm{Cd}, \mathrm{Mn}$, and other metals.

\section{MATERIALS AND METHODS}

\section{Sample Collection, Rhizobia Isolation and Soil Metal Measurements}

Soil samples and $L$. leucocephala seedlings were collected from the edge of a vanadium-titanium magnetite tailing reservoir (Figure 1), situated on the outskirts of Panzhihua city (N26 33'13.23"; E 101 ${ }^{\circ} 45^{\prime} 59.42^{\prime \prime}$; elevation $1219.3 \mathrm{~m}$ ). Healthy plants were carefully uprooted, stored in a sterile sampling bag, and shipped back to laboratory. Samples of the V-Ti magnetite tailing soil were taken from the topsoil $(0-20 \mathrm{~cm}$ deep) within an area of $4 \mathrm{~m}^{2}$ consisting of five sampling points near the plants. The isolation of rhizobia was carried out using Congo red-amended yeast mannitol agar (YMA) medium which comprised of $\left(1^{-1}\right.$ Milli-Q $\left.\mathrm{H}_{2} \mathrm{O}\right)$ : yeast extract $1.0 \mathrm{~g}$, mannitol $10.0 \mathrm{~g}, \mathrm{~K}_{2} \mathrm{HPO}_{4} 0.5 \mathrm{~g}, \mathrm{MgSO}_{4} 0.2 \mathrm{~g}, \mathrm{NaCl} 0.1 \mathrm{~g}, \mathrm{CaCO}_{3} 1.0 \mathrm{~g}$, agar $15.0 \mathrm{~g}$ and Congo red $0.025 \mathrm{~g}(\mathrm{pH} 6.8 \pm 0.2)$ (Somasegaran and Hoben, 2012). Fresh root nodules were initially washed with tap water to remove rhizosphere soil. Surface sterilization was performed by soaking root tissues in $75 \%(\mathrm{v} / \mathrm{v})$ ethanol for $5 \mathrm{~min}$ followed by $1 \%(\mathrm{v} / \mathrm{v})$ sodium hypochlorite for $3 \mathrm{~min}$ before they were finally rinsed for 3 times with sterile Milli-Q water (Zhang et al., 2018). Nodules were aseptically cut off from the roots and crushed in a sterile Eppendorf tube with a sterile glass rod. A loopful of the nodule suspension was streaked on a Congo redcontaining YMA plate, which was incubated in the dark at $28^{\circ} \mathrm{C}$ for at least $7 \mathrm{~d}$. Repeated streaking was performed on fresh plates until pure culture was obtained (Somasegaran and Hoben, 2012). Soil samples were thoroughly air-dried at room temperature, put through a sieve (pore size $2 \mathrm{~mm}$ ). and digested in Teflon crucibles 

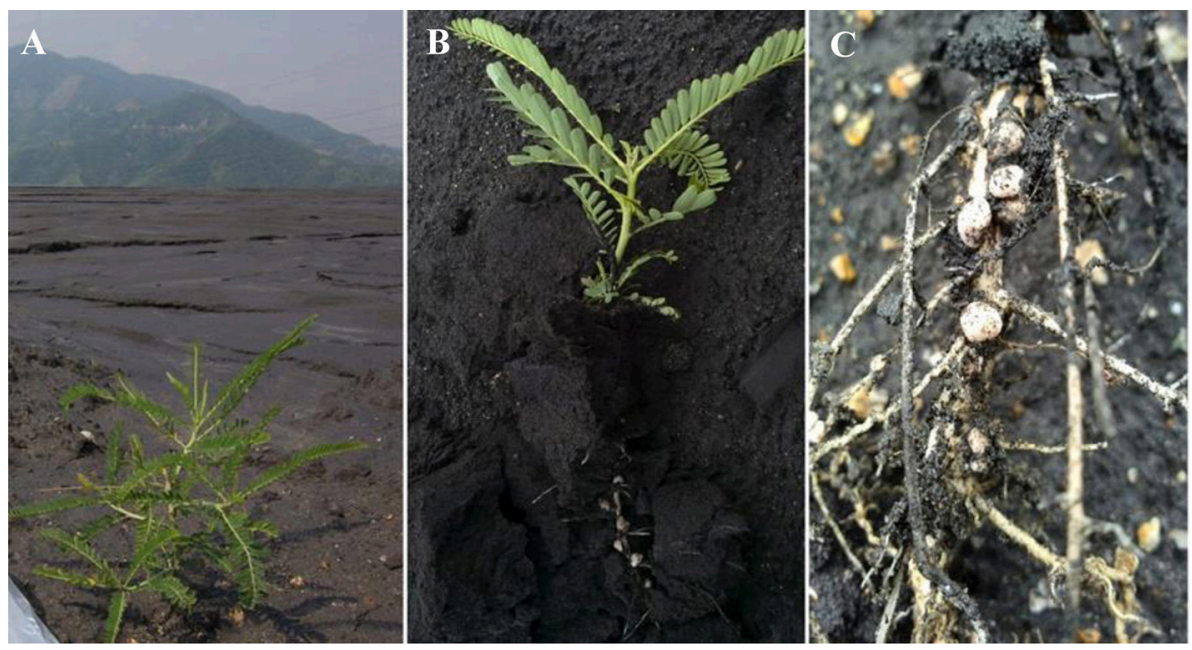

FIGURE 1 | (A) Sampling site at Majiatian V-Ti tailings reservoir in Panzhihua mining area and (B) a fresh plant sample of L. leucocephala with (C) vigorously growing root nodules thereon.

with a concentrated acid mixture of $\mathrm{HNO}_{3}, \mathrm{HF}$, and $\mathrm{HClO}_{4}$ $(5: 5: 3, \mathrm{v} / \mathrm{v} / \mathrm{v})$.

\section{Phylogenetic Analyses}

Liquid rhizobia culture was used for DNA extraction. The strain was grown in liquid mannitol broth and harvested when cell concentration reached $1 \times 10^{8} \mathrm{CFU} \mathrm{ml}^{-1}$. Genomic DNA was extracted using TIANamp Bacteria DNA Kit (TIANGEN Biotech, Beijing, China) following standard protocols prescribed by the manufacturer. Fragments of $16 \mathrm{~S}$ rRNA gene were amplified using the universal primers of 27F ( $5^{\prime}$-AGA GTT TGA TCC TGG CTC AG-3') and 1492R (5'-GGT TAC CTT GTT ACG ACT T-3') (Yu et al., 2014). PCR was performed in a $30 \mu \mathrm{l}$ buffer system using a Bio-rad T100 Thermo Cycler (Bio-rad, USA) according to the following protocol: an initial denaturation step at $94^{\circ} \mathrm{C}$ for $3 \mathrm{~min}, 30$ denaturation cycles at $94^{\circ} \mathrm{C}$ for $1 \mathrm{~min}$, an annealing step at $56^{\circ} \mathrm{C}$ for $1 \mathrm{~min}$, an extension step at $72^{\circ} \mathrm{C}$ for $2 \mathrm{~min}$ and a final extension at $72^{\circ} \mathrm{C}$ for $10 \mathrm{~min}$ (Tan et al., 1997). The nitrogen fixation gene nifH was amplified according to methods described by Laguerre et al. (2001). The amplification of housekeeping genes was carried out using the following primers at specific melting temperatures: atpD255F-atpD782R for atpD at $\mathrm{Tm} 58^{\circ} \mathrm{C}$, glnII12F-glnII689R for $g \ln I I$ at $\mathrm{Tm} 56^{\circ} \mathrm{C}$, recA63FrecA555R for recA at $\mathrm{Tm} 58^{\circ} \mathrm{C}$, and rpoB454F-rpoB1364R for $r p o B$ at $\mathrm{Tm} 65^{\circ} \mathrm{C}$ (Gaunt et al., 2001; Vinuesa et al., 2005, 2008). PCR products were subjected to electrophoresis in $1 \%$ agarose gel to verify the size of target fragments and afterwards sent to Tsing Ke Biological Technology (Chengdu, China) for sequencing. The determined sequences were then compared and aligned with those from known species on GenBank (NCBI, USA) using ClustalW in MEGA 6.0 package (Tamura et al., 2013). Phylogenetic trees were constructed using maximum likelihood method with Kimura 2-parameter (Kimura, 1980) and multilocus sequence analysis (MLSA) was carried out by constructing a single phylogenetic tree using the concatenated sequences of four housekeeping genes (Tak et al., 2016). The reliability of the phylogenetic trees was calculated based on 1,000 bootstrap repetitions. All sequences mentioned above were deposited in GenBank using BLASTn tool and a unique accession number was assigned to each.

\section{Metal Tolerance Tests}

The tolerance of rhizobia to cadmium (Cd) and manganese $(\mathrm{Mn})$ was assayed by spot-inoculating cell suspension on yeast mannitol agar. An aliquot of $10 \mu \mathrm{l}$ initial culture containing 1 $\times 10^{8} \mathrm{CFU} \mathrm{ml}{ }^{-1}$ cells obtained from yeast mannitol broth was pipetted on YMA plates supplemented with 50, 150, 250, and $400 \mathrm{mg} \mathrm{l}^{-1}$ of $\mathrm{Mn}^{2+}$ or $\mathrm{Cd}^{2+}$, respectively. Each treatment had at least three plates as replication and each plate was inoculated with three colonies at equal distance. All plates were maintained in an incubator for $7 \mathrm{~d}$ at $28^{\circ} \mathrm{C}$ in the dark. The metal tolerance was determined by calculating the ratio of the colony size of the experimental group to that of the control.

\section{Assay of Growth Promoting Traits}

Bacterial plant growth promoting abilities including indole3 -acetic acid (IAA) production, siderophore secretion and phosphate solubilization were estimated by measuring the concentrations of IAA, siderophore and solubilized phosphate in liquid media. For the determination of IAA production, rhizobia strains were grown in $5 \mathrm{ml}$ yeast mannitol broth (YMB) supplemented with L-tryptophan $\left(2.5 \mathrm{~g}^{-1}\right)$ at $28^{\circ} \mathrm{C}$ on a rotary shaker at $150 \mathrm{rpm}$ for 3 days. Culture supernatant was obtained by centrifugation at $8,000 \mathrm{rpm}$ for $5 \mathrm{~min}$. An aliquot of $2 \mathrm{ml}$ supernatant was mixed with $4 \mathrm{ml}$ Salkowski reagent $(2 \% 0.5 \mathrm{M}$ $\mathrm{FeCl}_{3}$ in $35 \% \mathrm{HClO}_{4}$ ) and immediately incubated in the dark for $30 \mathrm{~min}$ at room temperature (Datta and Basu, 2000). The optical density of the mixture after reaction was measured at a wavelength of $530 \mathrm{~nm}\left(\mathrm{OD}_{530}\right)$ using a spectrophotometer (WFJ2100, UNICO, China). The actual IAA concentration was calculated in accordance with a standard curve. Siderophore 
production was estimated using chrome azurol sulfonate (CAS) assay on solid plates according to the method described by Schwyn and Neilands (1987). Liquid National Botanical Research Institute's phosphate medium (NBRIP), which was used to perform quantitative assay of siderophore production, consisted of $\left(\mathrm{l}^{-1}\right.$ Milli-Q $\left.\mathrm{H}_{2} \mathrm{O}\right): \mathrm{MgCl}_{2} \cdot 6 \mathrm{H}_{2} \mathrm{O} 5.0 \mathrm{~g}, \mathrm{MgSO}_{4} \cdot 7 \mathrm{H}_{2} \mathrm{O} 0.25 \mathrm{~g}$, $\mathrm{KCl} 0.2 \mathrm{~g},\left(\mathrm{NH}_{4}\right)_{2} \mathrm{SO}_{4} 0.1 \mathrm{~g}, \mathrm{Ca}_{3}\left(\mathrm{PO}_{4}\right)_{2} 5.0 \mathrm{~g}$ and glucose $10.0 \mathrm{~g}$. The medium was adjusted to $\mathrm{pH} 7.0 \pm 0.2$ before sterilization at $115^{\circ} \mathrm{C}$ for $15 \mathrm{~min}$. An aliquot of $1 \mathrm{ml}$ bacterial start culture $\left(1 \times 10^{8} \mathrm{CFU} \mathrm{ml}{ }^{-1}\right)$ was inoculated into a $250 \mathrm{ml}$ Erlenmeyer flask containing $100 \mathrm{ml}$ medium and incubated on a rotary shaker at $150 \mathrm{rpm}$ for 7 days at $28^{\circ} \mathrm{C}$ (Nautiyal, 1999). The vanadium molybdate blue colorimetric method was employed for the quantification of phosphate, where the absorbance at $660 \mathrm{~nm}$ was measured using a spectrophotometer (WFJ2100, UNICO, China) (Walker et al., 2004).

\section{Pot Culture Experiment}

To assess the effectiveness of the leucaena-rhizobia remediation system, pot culture experiment was carried out in both tailings and metal-spiked soils using Leonard jar apparatus (Somasegaran and Hoben, 2012), which was composed of two parts, i.e., the jar at the bottom $(10 \times 14 \mathrm{~cm})$ containing plant nutrient solution and the pot $(7 \times 15 \mathrm{~cm})$ at the top filled with substrate. These two parts were connected by a cotton wick to keep a steady supply of nutrients to the substrate in the pot, and joined together by a sealed screw cap to prevent microbial contamination from the air (Supplementary Figure S1). The jar contained 1 L of nitrogenfree nutrient solution ( $\mathrm{Yu}$ et al., 2016) which consisted of ( $\mathrm{l}^{-1}$ Milli-Q $\mathrm{H}_{2} \mathrm{O}$ ): $\mathrm{KCl} 0.5 \mathrm{~g}, \mathrm{CaSO}_{4} \cdot 2 \mathrm{H}_{2} \mathrm{O} 0.2 \mathrm{~g}, \mathrm{MgSO}_{4} \cdot 7 \mathrm{H}_{2} \mathrm{O}$ $0.2 \mathrm{~g}, \mathrm{KH}_{2} \mathrm{PO}_{4} 0.2 \mathrm{~g}$, Fe-EDTA $0.001 \mathrm{~g}, \mathrm{KNO}_{3} 1 \mathrm{~g}$, trace elements (containing $\mathrm{H}_{3} \mathrm{BO}_{3} 0.1 \mathrm{~g}, \mathrm{ZnSO}_{4} \cdot 7 \mathrm{H}_{2} \mathrm{O} 0.1 \mathrm{~g}, \mathrm{CuSO}_{4} \cdot 5 \mathrm{H}_{2} \mathrm{O}$ $0.05 \mathrm{~g}, \mathrm{MnCl}_{2} \cdot 4 \mathrm{H}_{2} \mathrm{O} 0.05 \mathrm{~g}$ and $\mathrm{Na}_{2} \mathrm{MoO}_{4} \cdot 2 \mathrm{H}_{2} \mathrm{O} 0.01 \mathrm{~g}$ ), and $\mathrm{CaCO}_{3} 2 \mathrm{~g}$ which was added to the final solution and stirred well. Vermiculite was used as substrate for the pot culture experiment with added metals. Stock solutions of $\mathrm{CdCl}_{2}$ and $\mathrm{MnCl}_{2}$ were separately prepared in Milli-Q water. Metal-spiked vermiculite was prepared by adding $190 \mathrm{ml}$ of the stock solution to vermiculite ( $200 \mathrm{~g}$ dry wt) to achieve desired concentrations at 5,20 , and $35 \mathrm{mg} \mathrm{kg}^{-1} \mathrm{Cd}$ or $\mathrm{Mn}$ in the substrate. The apparatus was assembled by filling the pot with vermiculite to $90 \%$ and autoclaved at $115^{\circ} \mathrm{C}$ for $30 \mathrm{~min}$. Homogeneity was tested by measuring vermiculite samples randomly taken from at least five spots across different depths. Physico-chemical properties of $\mathrm{V}$-Ti magnetite tailings and vermiculite were determined using standard methods (Pansu and Gautheyrou, 2007). Seeds of L. leucocephala were surface sterilized by soaking in $95 \%$ alcohol for $10 \mathrm{~s}$ and in $5 \%$ sodium hypochlorite solution for $5 \mathrm{~min}$ before they were rinsed with at least 10 changes of sterile MilliQ water (Somasegaran and Hoben, 2012). After sterilization, the seeds were placed on plain agar $(0.05 \%)$ for germination at $25^{\circ} \mathrm{C}$ in the dark. Three burgeoning seeds were aseptically transferred into each pot and inoculated with $1 \mathrm{ml}$ rhizobial suspension at the root of each seedling. After this, a layer of $1 \mathrm{~cm}$ autoclaved quartz sand was placed on top of the vermiculite to ensure seedlings grew in a sterile environment. Each metal concentration had three pots as replication and non-inoculated plants served as the control group. The plants were grown in a greenhouse for a total length of 6 months at a day temperature of $25^{\circ} \mathrm{C}$ for $16 \mathrm{~h}$ and night temperature of $17^{\circ} \mathrm{C}$ for $8 \mathrm{~h}$. Upon harvest, nodule number, plant height and root length were measured and freshly harvested samples of L. leucocephala were immediately oven-dried at $105^{\circ} \mathrm{C}$ for $30 \mathrm{~min}$ and maintained at $80^{\circ} \mathrm{C}$ until constant weight. Dried plant samples were pulverized for following experimentation.

\section{Determination of Plant Metal Contents}

Dried tissues of the leucaena plants were finely ground and digested with a concentrated mixture of $\mathrm{HNO}_{3}$ and $\mathrm{HClO}_{4}$ (5:1, $\mathrm{v} / \mathrm{v}$ ) prior to the measurement of heavy metal concentrations using ICP-AES (IRIS Intrepid II, Thermo Electron, USA). The remediation capabilities of L. leucocephala-rhizhobia system were determined by calculating bioconcentration coefficient factor (BCF) and translocation factor (TF), which were defined as follows: $\mathrm{BCF}=$ root metal content $\left(\mathrm{mg} \mathrm{kg}^{-1}\right) /$ soil metal content $\left(\mathrm{mg} \mathrm{kg}^{-1}\right) ; \mathrm{TF}=$ shoot metal content $\left(\mathrm{mg} \mathrm{kg}^{-1}\right) /$ root metal content $\left(\mathrm{mg} \mathrm{kg}^{-1}\right)$.

\section{Determination of $\mathbf{N}, \mathrm{P}$, and $\mathrm{K}$ in Plants}

Plant samples were digested by sulphuric acid prior to the determination of nitrogen $(\mathrm{N})$ using indophenol blue method, phosphorus (P) using vanadium molybdate method, and potassium (K) using a flame photometer (FP6410, Shanghai Precision \& Scientific, China) (Novozamsky et al., 1974).

\section{Statistical Analyses}

Statistical analyses were done using the SPSS 22.0 package. Data were expressed as mean values \pm standard deviations calculated using Microsoft Excel 2013. For the analyses of symbiotic effects and metal contents in plants, means between different metal treatments were compared using one-way analysis of variance (ANOVA) and least significant difference (LSD) test. Means between the inoculated and non-inoculated groups at each metal concentration were compared using Tukey's posthoc test. Differences were considered statistically significant at $P<0.05$.

\section{RESULTS}

\section{Metal Contents of V-Ti Magnetite Tailing Soil}

Heavy metal assay revealed that the topsoil of V-Ti magnetite tailings at Panzhihua mainly contained 7 heavy metal elements (Table 1). Exceedingly high amounts of $\mathrm{Fe}\left(143.3 \mathrm{~g} \mathrm{~kg}^{-1}\right)$ and $\mathrm{Ti}$ $\left(35.7 \mathrm{~g} \mathrm{~kg}^{-1}\right)$ were found. However, the concentration of $\mathrm{V}$ was only $0.3 \mathrm{~g} \mathrm{~kg}^{-1}$. Compared to $\mathrm{Fe}, \mathrm{Ti}$, and $\mathrm{V}, \mathrm{Mn}\left(2.8 \mathrm{~g} \mathrm{~kg}^{-1}\right), \mathrm{Cu}$ (58.4 $\left.\mathrm{mg} \mathrm{kg}^{-1}\right)$, $\mathrm{Ni}\left(92.3 \mathrm{mg} \mathrm{kg}^{-1}\right)$, and $\mathrm{Cd}\left(7.1 \mathrm{mg} \mathrm{kg}^{-1}\right)$ existed in moderate amounts.

\section{Identification of Isolate YH1}

All successfully amplified nucleotide sequences of isolate $\mathrm{YH} 1$ for phylogenetic analysis were uploaded to GenBank and accession numbers were obtained (KU904504, 16S rRNA; KU904541, nifH; KU904549, atpD; KU904591, glnII; KU904570, recA; 


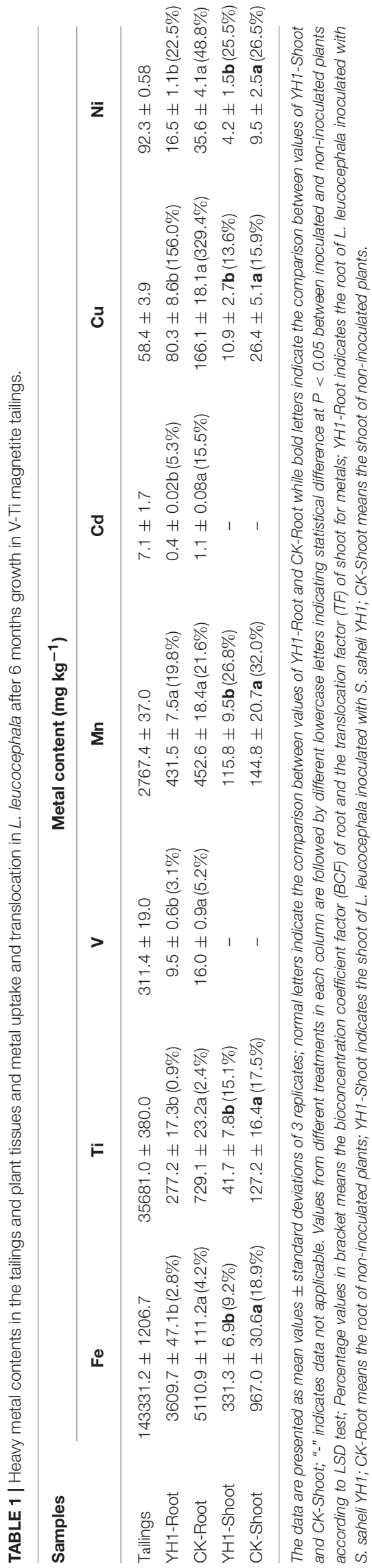

KU904612, rрoB). The isolate was clustered into the same group with 99.9\% similarity with Sinorhizobium saheli LMG7837 in the $16 \mathrm{~S}$ rRNA phylogenetic tree (Figure 2). Therefore, it was preliminarily classified as belonging to Sinorhizobium. Moreover, the concatenated tree of the four housekeeping genes $(a t p D-g \ln I I-r e c A-r p o B)$ assigned $\mathrm{YH} 1$ to the same branch with Sinorhizobium saheli with 99.0\% homology (Figure 3). Therefore, isolate YH1 was identified as Sinorhizobium saheli. The nitrogenase reductase gene $(n i f H)$ tree which consisted of 12 other known species was constructed and it showed that the nifH gene of strain YH1 shared $99.0 \%$ similarity with that of Neorhizobium huautlense (CCBAU 65798T) (Figure 4).

\section{Metal Tolerance of YH1}

Metal tolerance test revealed that vigorous growth of YH1 was observed at $50 \mathrm{mg} \mathrm{kg}^{-1} \mathrm{Cd}$ and $250 \mathrm{mg} \mathrm{kg}^{-1} \mathrm{Mn}$, indicating its strong tolerance to these metals. Therefore, the metals of Cd and $\mathrm{Mn}$ were selected as metal contaminants for pot culture experiments to further explore the synergism of S. saheli $\mathrm{YH} 1$ with L. leucocephala.

\section{PGP Traits of YH1}

S. saheli YH1 secreted $166.77 \pm 2.03 \mathrm{mg} \mathrm{l}^{-1}$ IAA in Ltryptophan-containing YMB medium after 3 days growth. An amount of $104.41 \pm 7.48 \mathrm{mg} \mathrm{l}^{-1}$ soluble phosphate was detected in the supernatant of NBRIP after 7 days incubation. However, S. saheli $\mathrm{YH1}$ did not show siderophore producing activity.

\section{Remediation Effects in V-Ti Magnetite Tailings}

The physico-chemical analysis showed that the tailing samples were at $\mathrm{pH} 6.66 \pm 0.37$ and contained $8.51 \pm 0.43 \mathrm{mg} \mathrm{kg}-1$ available nitrogen, $23.98 \pm 2.33 \mathrm{mg} \mathrm{kg}^{-1}$ available phosphorus and $13.56 \pm 1.11 \mathrm{mg} \mathrm{kg}^{-1}$ available potassium. L. leucocephala was nodulated by $S$. saheli $\mathrm{YH} 1$ in $\mathrm{V}$-Ti mine tailings after 6 months growth, while no nodules were found on the roots in the control group. The nodule number was on average 38 for each inoculated plant. In general, the inoculation of YH1 led to $10.0 \%$ increase in plant nitrogen content and a significant increase $(P<0.05)$ in plant height and root length by 39.5 and $27.2 \%$ respectively (Table 2 ). There was also a significant $(P<0.05)$ increase of the plant biomass by $67.2 \%$ in comparison with the non-inoculated control. The contents of phosphorus and potassium were also significantly $(P<0.05)$ elevated by 112.2 and $25.0 \%$, respectively (Table 2 ).

The amounts of metal uptake in L. leucocephala roots from the $\mathrm{V}$-Ti magnetite tailing soil are in the following order: $\mathrm{Fe}>\mathrm{Mn}>\mathrm{Ti}>\mathrm{Cu}>\mathrm{Ni}>\mathrm{V}>\mathrm{Cd}$ for inoculated plants and $\mathrm{Fe}>\mathrm{Ti}>\mathrm{Mn}>\mathrm{Cu}>\mathrm{Ni}>\mathrm{V}>\mathrm{Cd}$ for control group. Overall, the uptake of $\mathrm{Cd}$ was most while that of Mn was least effectively reduced. Comparing with inoculation-free plants, S. saheli $\mathrm{YH} 1$ significantly $(P<0.05)$ reduced metal uptake in roots, with the reduction rates for the tested metals ranging from 8.4 to $65.5 \%$.

The translocation of these metals showed that only $\mathrm{Fe}, \mathrm{Ti}$, $\mathrm{Mn}, \mathrm{Cu}$, and $\mathrm{Ni}$ were transferred from roots to shoots. TF values 


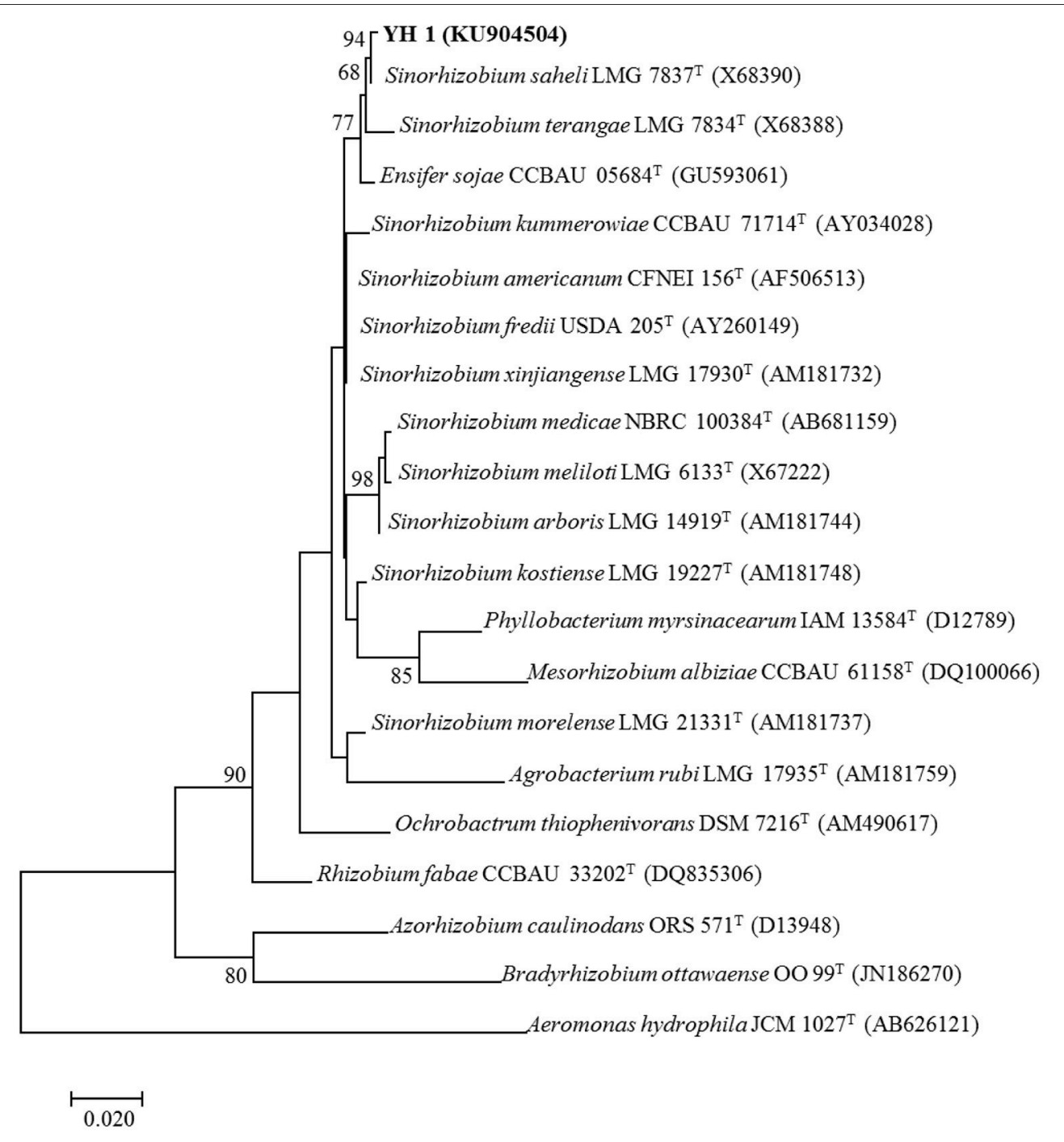

FIGURE 2 | 16S rRNA phylogenetic tree (1,404 bp) of L. leucocephala-isolated strain YH1 created using maximum likelihood method with the Kimura 2-parameter model. Bootstrap confidence level is based on 1,000 iterations. Accession numbers retrieved from GenBank are shown in parentheses. The scale bar implies $2 \%$ nucleotide substitutions per site. Values lower than 50 are not shown at the nodes. Superscript "T" following each strain number indicates type strain.

for these transferred metals ranged from 9.2 to $26.8 \%$ for the inoculated plants and from 15.9 to $32.0 \%$ for the non-inoculated plants. The amount of Fe transferred was the highest among all metals tested in both inoculated and control groups, the former amounting to $331.3 \mathrm{mg} \mathrm{kg}^{-1}$ and the latter $967.0 \mathrm{mg} \mathrm{kg}^{-1}$. The inoculation of $\mathrm{YH} 1$ prevented these metals from moving to shoots, leading to a significant reduction $(P<0.05)$ of TF values for the inoculated plants. However, in the case of Fe, the inoculated plants exhibited less than $50 \%$ reduction in the amounts of the translocated metals compared with the control plants.

\section{Remediation Effects in Cd/Mn Soil}

The non-spiked vermiculite was at $\mathrm{pH} 7.06 \pm 0.04$ and had the following properties: $56.02 \pm 13.60 \mathrm{mg} \mathrm{kg}^{-1}$ total phosphorus, $0.67 \pm 0.05 \mathrm{mg} \mathrm{kg}^{-1}$ available phosphorous, $15.75 \pm 1.29 \mathrm{~g} \mathrm{~kg}^{-1}$ total potassium, and $75.80 \pm 3.66 \mathrm{mg} \mathrm{kg}^{-1}$ available potassium. No nitrogen contents were detected for vermiculite.

\section{Metal Uptake by Plants}

In all plants inoculated with L. leucocephala grown in Cd- or Mn-amended soils, uptake of both metals by the plants was decreased compared to the control. Root uptake of Cd was positively correlated with the Cd content in control group, while it remained at a low level in all three inoculated treatments. The highest amount of Cd uptake was found in the soil added with $35 \mathrm{mg} \mathrm{kg}^{-1} \mathrm{Cd}$, where the roots of inoculation-free plants contained $281.33 \pm 61.24 \mathrm{mg} \mathrm{kg}^{-1} \mathrm{Cd}, 79.9 \%$ higher than in the YH1-inoculated group (56.43 $\left.\pm 11.14 \mathrm{mg} \mathrm{kg}^{-1}\right)$ (Figure 5A). However, shoot Cd contents in plants with $\mathrm{YH} 1$ inoculation were only slightly reduced (Figure 5B) compared to the control at all three soil $\mathrm{Cd}$ concentrations. There was no correlation of 


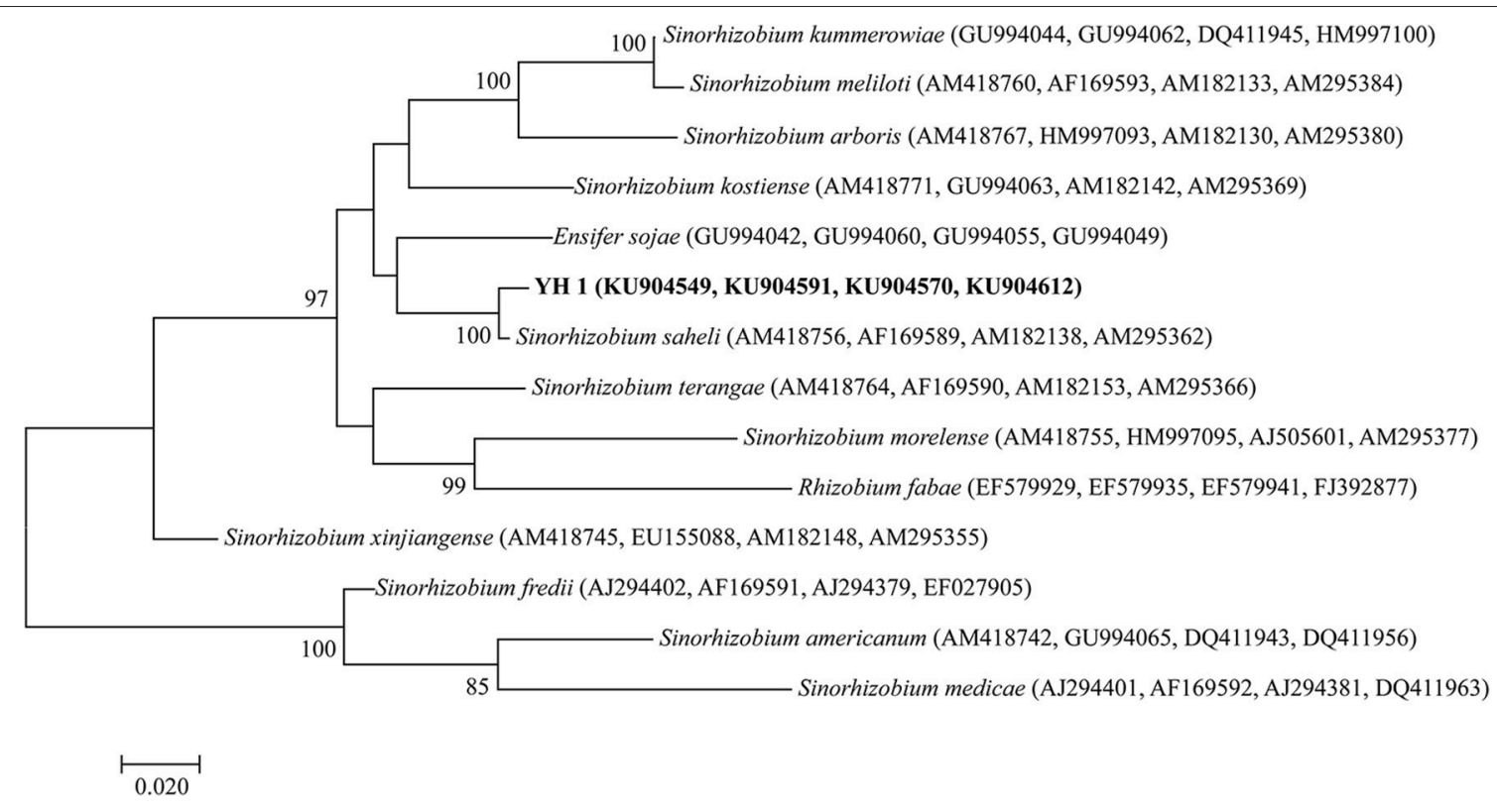

FIGURE 3 | Concatenated tree of $L$. leucocephala-isolated strain YH1 combining atpD-glnll-recA-rpoB (1,631 bp), generated using maximum likelihood method (Kimura 2-parameter model) with 1,000 repetitions of bootstrap value. Accession numbers retrieved from GenBank are shown in parentheses. The scale bar denotes $2 \%$ nucleotide substitutions per site. Values lower than 50 are not shown at the nodes.

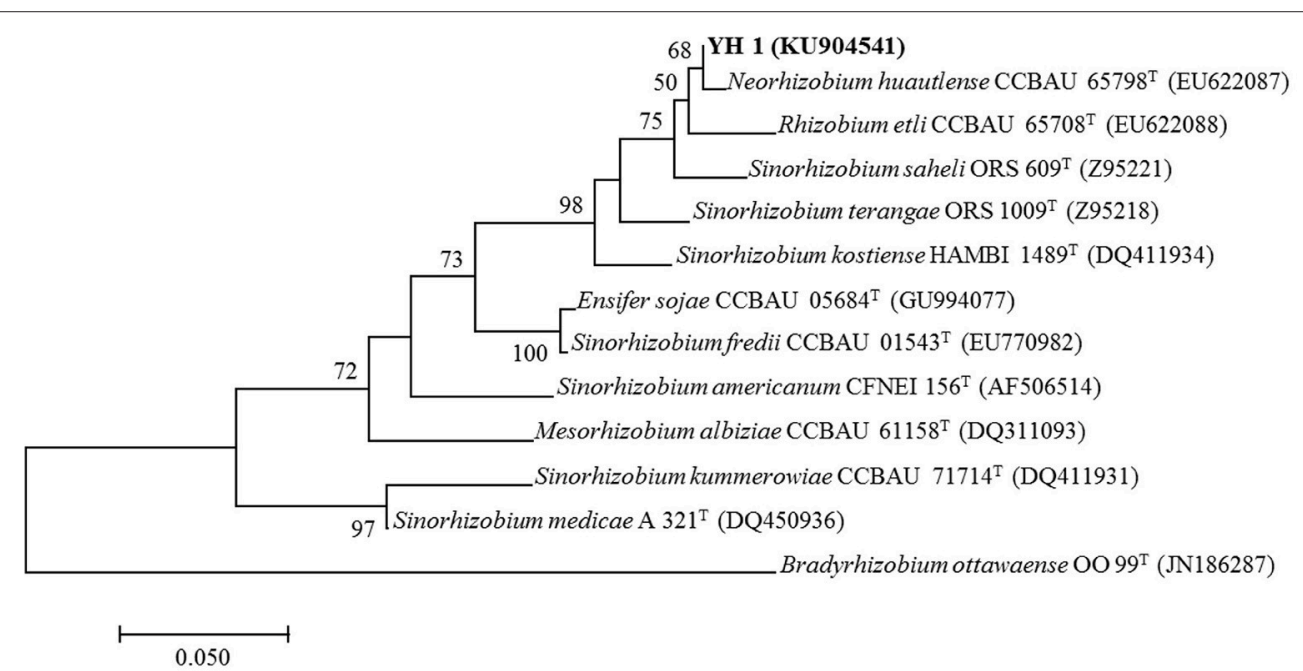

FIGURE 4 | Maximum likelihood tree of nifH sequences (453 bp) for L. leucocephala-isolated strain YH1 constructed using the Kimura 2-parameter model with bootstrap confidence based on 1,000 repetitions. Accession numbers retrieved from GenBank are shown in parentheses. The scale bar denotes $5 \%$ nucleotide substitutions per site. Values lower than 50 are not shown at the nodes. Superscript "T" following each strain number indicates type strain.

shoot Cd content to the soil Cd content in both groups. The highest amount of shoot $\mathrm{Cd}$ content in control group was 8.96 $\pm 4.87 \mathrm{mg} \mathrm{kg}^{-1}$ in the soil treated with $5 \mathrm{mg} \mathrm{kg}^{-1} \mathrm{Cd}$, while in inoculated group was $4.78 \pm 0.61 \mathrm{mg} \mathrm{kg}^{-1}$ at $20 \mathrm{mg} \mathrm{kg}^{-1}$ soil Cd.

Root Mn contents in inoculated plants at all levels of soil Mn were also lower than in the control group (Figure 5C). In the presence of $35 \mathrm{mg} \mathrm{kg}^{-1} \mathrm{Mn}$ in soil, the biological concentration factor (BCF) for Mn was reduced by $67.6 \%$ compared with the non-inoculated control. Shoot Mn contents in all inoculated plants were apparently reduced compared to the control, and in treatments with 20 and $35 \mathrm{mg} \mathrm{kg}^{-1}$ soil $\mathrm{Mn}$, shoot $\mathrm{Mn}$ contents were significantly $(P<0.05)$ reduced by 64.1 and $78.9 \%$ respectively (Figure 5D).

\section{Symbiosis and Nitrogen Fixation}

All plants with inoculation of strain YH1 exhibited formation of root nodules. Less nodules were produced in plants treated 
TABLE 2 | Symbiotic nitrogen-fixing and PGP effects of strain YH1 on L. leucocephala after 6 months growth in V-Ti mine tailings and vermiculite supplemented with different concentrations of $\mathrm{Cd}$ or $\mathrm{Mn}$.

\begin{tabular}{|c|c|c|c|c|c|c|c|c|}
\hline Pot soil & Treatment & Nodule number & Plant height (cm) & $\begin{array}{l}\text { Root length } \\
\text { (cm) }\end{array}$ & $\begin{array}{c}\text { Total dry } \\
\text { weight (g) }\end{array}$ & $\begin{array}{l}\text { Total } N \\
\left(\mathrm{~g} \mathrm{~kg}^{-1}\right)\end{array}$ & $\begin{array}{c}\text { Total P } \\
\left(\mathrm{g} \mathrm{kg}^{-1}\right)\end{array}$ & $\begin{array}{c}\text { Total K } \\
\left(\mathrm{g} \mathrm{kg}^{-1}\right)\end{array}$ \\
\hline \multirow[t]{2}{*}{ Tailings } & $\mathrm{YH} 1$ & $32 \pm 2 a b$ & $16.6 \pm 0.7 a b^{*}$ & $15.1 \pm 2.5 c$ & $1.0 \pm 0.2 \mathbf{a}$ & $9.4 \pm 0.1 b c$ & $1.8 \pm 0.1 a b^{\star}$ & $18.5 \pm 0.5 \mathbf{a}^{*}$ \\
\hline & CK & 0 & $11.9 \pm 0.9 b$ & $10.1 \pm 2.3 d$ & $0.6 \pm 0.2 \mathbf{a}$ & $9.0 \pm 1.0 b$ & $0.9 \pm 0.1 d$ & $14.9 \pm 1.2 \mathrm{ab}$ \\
\hline \multirow[t]{2}{*}{$\mathrm{Cd}\left(5 \mathrm{mg} \mathrm{kg}{ }^{-1}\right)$} & $\mathrm{YH1}$ & $23 \pm 5 b c$ & $15.1 \pm 2.2 \mathrm{ab}$ & $23.6 \pm 1.0 a b^{\star}$ & $0.3 \pm 0.0 c$ & $8.2 \pm 0.3 b c$ & $1.6 \pm 0.2 \mathrm{ab}$ & $15.7 \pm 0.6 a b$ \\
\hline & CK & 0 & $16.3 \pm 2.8 a$ & $12.6 \pm 0.7 \mathrm{~cd}$ & $0.3 \pm 0.1 c$ & $8.2 \pm 0.2 b$ & $1.1 \pm 0.1 \mathrm{~cd}$ & $10.7 \pm 1.8 \mathrm{c}$ \\
\hline \multirow[t]{2}{*}{$\mathrm{Cd}\left(20 \mathrm{mg} \mathrm{kg}^{-1}\right)$} & $\mathrm{YH} 1$ & $23 \pm 5 b c$ & $12.7 \pm 4.7 b$ & $23.8 \pm 2.1 a b^{*}$ & $0.5 \pm 0.1 b c$ & $8.0 \pm 0.8 c$ & $1.3 \pm 0.1 b c$ & $15.4 \pm 0.4 a b$ \\
\hline & $\mathrm{CK}$ & 0 & $17.3 \pm 0.9 a$ & $16.6 \pm 1.7 \mathrm{bc}$ & $0.4 \pm 0.1 \mathrm{abc}$ & $8.9 \pm 0.1 b$ & $1.5 \pm 0.3 b c$ & $14.2 \pm 0.8 a b$ \\
\hline \multirow[t]{2}{*}{$\mathrm{Cd}\left(35 \mathrm{mg} \mathrm{kg}^{-1}\right)$} & $\mathrm{YH} 1$ & $27 \pm 5 a b c$ & $15.7 \pm 2.1 \mathrm{ab}$ & $27.1 \pm 2.9 \mathbf{a}^{\star}$ & $0.5 \pm 0.0 \mathrm{bc}$ & $9.3 \pm 0.8 b c$ & $1.2 \pm 0.1 \mathrm{bc}$ & $15.1 \pm 2.5 a b$ \\
\hline & CK & 0 & $17.3 \pm 1.4 \mathbf{a}$ & $16.2 \pm 2.5 c$ & $0.4 \pm 0.1 \mathrm{bc}$ & $11.5 \pm 0.8 \mathbf{a}$ & $1.1 \pm 0.1 \mathrm{~cd}$ & $12.0 \pm 0.3 b c$ \\
\hline \multirow[t]{2}{*}{$\mathrm{Mn}\left(5 \mathrm{mg} \mathrm{kg}{ }^{-1}\right)$} & $\mathrm{YH} 1$ & $33 \pm 5 a b$ & $19.6 \pm 3.2 \mathrm{ab}$ & $19.5 \pm 1.5 \mathrm{bc}$ & $0.6 \pm 0.1 b c$ & $9.2 \pm 0.8 b c$ & $1.6 \pm 0.1 b^{*}$ & $17.0 \pm 1.7 \mathrm{ab}$ \\
\hline & $\mathrm{CK}$ & 0 & $16.7 \pm 1.1 \mathrm{a}$ & $21.0 \pm 1.5 a b$ & $0.5 \pm 0.0 \mathrm{ab}$ & $8.8 \pm 1.4 b$ & $0.9 \pm 0.1 d$ & $14.0 \pm 0.7 a b$ \\
\hline \multirow[t]{2}{*}{$\mathrm{Mn}\left(20 \mathrm{mg} \mathrm{kg}^{-1}\right)$} & $\mathrm{YH} 1$ & $33 \pm 9 a b$ & $17.2 \pm 2.5 a b$ & $20.1 \pm 3.4 \mathrm{bc}$ & $0.7 \pm 0.1 b$ & $8.0 \pm 0.4 c$ & $1.2 \pm 0.0 \mathrm{bc}$ & $18.5 \pm 0.0 \mathrm{a}$ \\
\hline & CK & 0 & $16.1 \pm 0.7 a$ & $21.0 \pm 1.6 a b$ & $0.6 \pm 0.0 \mathrm{a}$ & $7.8 \pm 0.9 b$ & $1.6 \pm 0.3 b$ & $16.3 \pm 0.5 \mathbf{a}$ \\
\hline \multirow[t]{2}{*}{$\mathrm{Mn}\left(35 \mathrm{mg} \mathrm{kg}^{-1}\right)$} & $\mathrm{YH} 1$ & $17 \pm 5 c$ & $15.1 \pm 2.6 a b$ & $22.3 \pm 3.2 \mathrm{ab}$ & $0.5 \pm 0.1 b c$ & $10.7 \pm 1.6 a b$ & $0.5 \pm 0.1 c$ & $14.3 \pm 0.8 b$ \\
\hline & CK & 0 & $14.5 \pm 1.5 a b$ & $17.1 \pm 3.3 \mathrm{bc}$ & $0.3 \pm 0.1 c$ & $9.6 \pm 0.3 a b$ & $1.5 \pm 0.1 b c^{*}$ & $12.0 \pm 0.9 b c$ \\
\hline \multirow[t]{2}{*}{$\mathrm{NA}(0)$} & $\mathrm{YH} 1$ & $40 \pm 8 \mathbf{a}$ & $21.7 \pm 3.4 \mathbf{a}$ & $22.0 \pm 1.4 \mathrm{ab}$ & $0.5 \pm 0.1 b c$ & $12.2 \pm 0.2 \mathbf{a}^{\star}$ & $2.5 \pm 0.8 \mathbf{a}$ & $16.3 \pm 0.7 a b$ \\
\hline & $\mathrm{CK}$ & 0 & $15.7 \pm 2.5 a$ & $23.1 \pm 1.7 \mathbf{a}$ & $0.5 \pm 0.1 \mathrm{abc}$ & $9.8 \pm 0.0 a b$ & $2.2 \pm 0.2 \mathbf{a}$ & $13.4 \pm 0.2 b c$ \\
\hline
\end{tabular}

The data are presented as mean values \pm standard deviations of three replicates. "CK" indicates the non-inoculated control plants. "NA (0)" denotes the plants in non-spiked vermiculite.

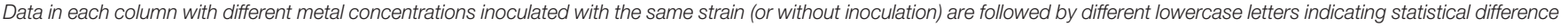

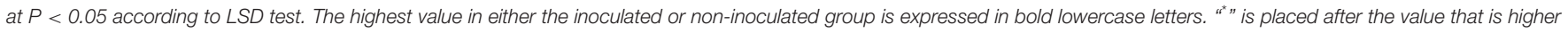
the other with statistical significance $(P<0.05)$ between the inoculated and non-inoculated groups at each metal concentration according to Tukey's post-hoc test.

with 5,20 , and $35 \mathrm{mg} \mathrm{kg}^{-1}$ cadmium than in those grown in $\mathrm{Cd}$-free control. With the increasing amount of manganese in the background from 0 to $20 \mathrm{mg} \mathrm{kg}^{-1}$, the number of nodules was reduced (Table 2). However, more nodules were found in $35 \mathrm{mg} \mathrm{kg}^{-1} \mathrm{Cd}$ soil. There was no significant difference between nodule numbers for plants grown in both metal-spiked soils at all concentrations.

\section{Biomass Yield}

After growing for 6 months under greenhouse conditions, all inoculated groups saw a slightly improved biomass yield in the presence of both metals. Among all metal-treated plants, dry weight was increased with the inoculation of YH1, except for plants in $5 \mathrm{mg} \mathrm{kg}^{-1} \mathrm{Cd}$ soil, where biomass remained the same for both groups (Table 2). However, the total dry weight of YH1inoculated plants in 5,20 , and $35 \mathrm{mg} \mathrm{kg}^{-1} \mathrm{Cd}$ soils did not show apparent difference compared to either inoculation-free or non-spiked control.

The biomass yield pattern for Mn-treated plants was different from that for Cd-treated plants. Dry weight of both inoculated plants and control showed positive correlation to Mn content ranging from 0 to $20 \mathrm{mg} \mathrm{kg}^{-1}$. However, in $35 \mathrm{mg} \mathrm{kg}^{-1} \mathrm{Mn}$ soil, biomass yield of both groups decreased. YH1-free plants showed a significant decrease of biomass at $35 \mathrm{mg} \mathrm{kg}^{-1}$ soil Mn compared to all treatments with lower Mn contents (Table 2).

\section{Plant Height and Root Length}

For inoculation-free plants in $0,5,20$, and $35 \mathrm{mg} \mathrm{kg}^{-1} \mathrm{Cd}$ soils (Table 2), no significant difference in plant height was found. In the inoculated group, plant height was reduced in the presence of different concentrations of $\mathrm{Cd}$ in soil. Only in non-spiked treatment, inoculated plants appeared to be higher than the control. YH1-inoculated plants showed a significant increase $(P<0.05)$ in root length by $86.9,44.2$ and $67.5 \%$ at 5,20 , and $35 \mathrm{mg} \mathrm{kg}^{-1}$ soil Cd respectively, except in the non-spiked control group, where $\mathrm{YH} 1$ did not contribute to the increase of root length. It showed that plant height was negatively correlated with the Mn content in soil for both YH1 and YH1-free groups. The introduction of YH1 led to a slight increase of plant height compared to plants without inoculation at 5,20 , and $30 \mathrm{mg} \mathrm{kg}^{-1}$ soil Mn (Table 2).

\section{DISCUSSION}

\section{Rhizobia Identification}

L. leucocephala-associated sinorhizobia in this region have been previously identified as nearest neighbors to $S$. americanum, $S$. fredii, S. kummerowiae, S. meliloti, S. mexicanus, S. saheli, and S. xinjiangense (Xu et al., 2013a,b). The existence of various toxic metals tends to exercise a natural selection process, through which metal-tolerant species are favored (Rajkumar et al., 2009). As was shown by our results, L. leucocephala was still able to grow vigorously and produce nitrogen-fixing nodules regardless of the presence of elevated amounts of toxic metals and the infertility in the V-Ti mine tailings, indicating the successful establishment of synergism between rhizobia and the host.

Both 16 rRNA and MLSA results identified strain YH1 as the closest neighbor to Sinorhizobium saheli (99.0\% similarity), which is widely reported as a beneficial rhizobium to colonize L. leucocephala (Wang et al., 2006; Ardley, 2017). It is well known that the dinitrogenase reductase enzyme encoding nifH is accountable for the formation of root nodules with nitrogen-fixing capability (Laguerre et al., 2001). In our work, the symbiotic gene nifH of Sinorhizobium strain YH1 was 

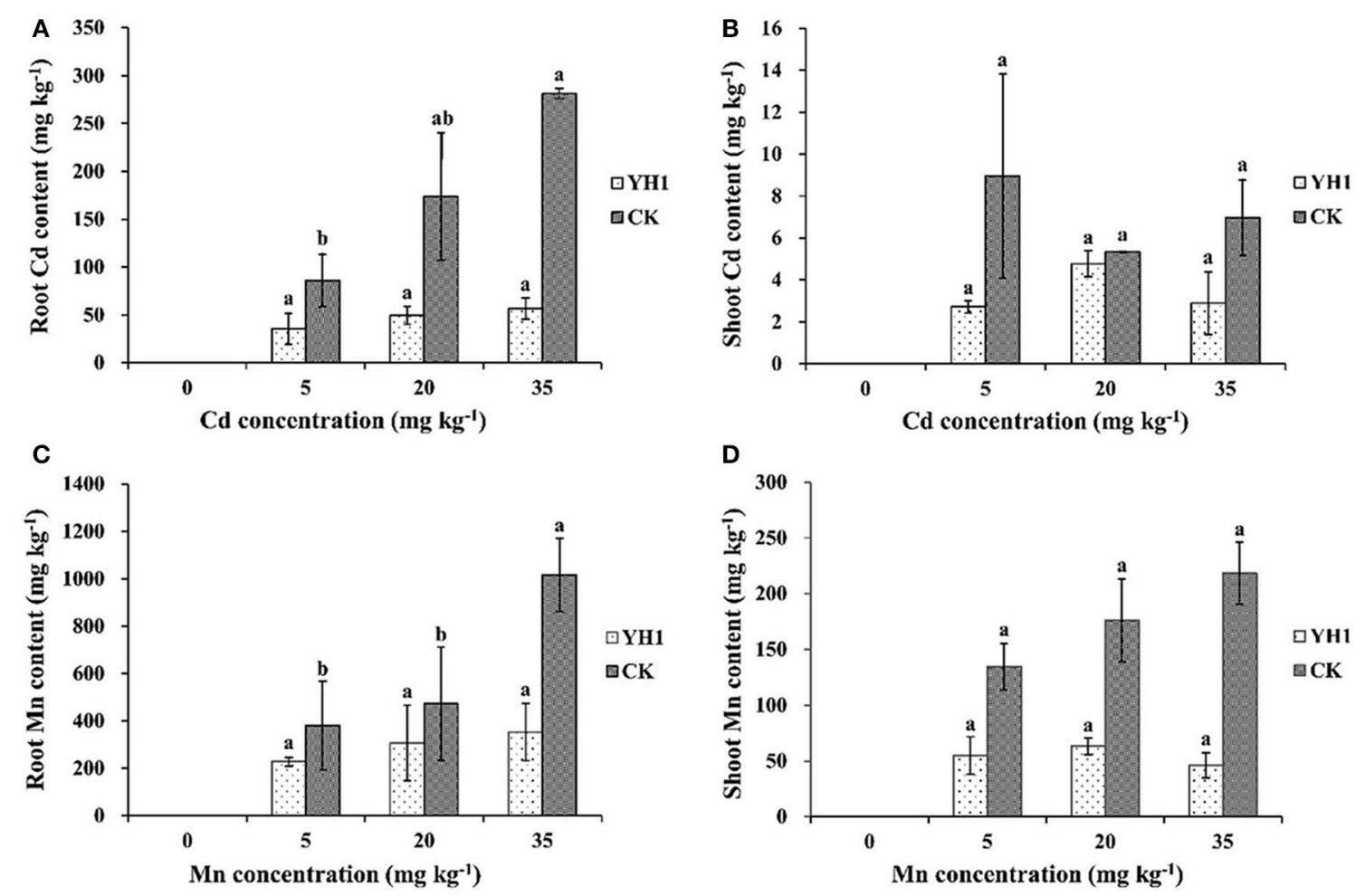

FIGURE 5 | Cd contents in (A) shoot and (B) root, Mn contents in (C) root and (D) shoot of L. leucocephala after 6 months growth in vermiculite supplemented with three different concentrations of $\mathrm{Cd}$ or $\mathrm{Mn}$. $\mathrm{YH} 1$, plants inoculated with strain $\mathrm{YH}$ 1; $\mathrm{CK}$, control group without inoculation. Different lowercase letters following data in either the $\mathrm{YH} 1$-inoculated or the $\mathrm{YH} 1$-free control group treated with different concentrations of the same metal show the statistical difference is significant at $P<0.05$ according to LSD test. Error bars represent standard deviations.

clustered nearer to Neorhizobium huautlense (formerly known as Rhizobium huautlense) CCBAU 65798 with 99.6\% homogeny than to Sinorhizobium saheli which only had $97.1 \%$ similarity. This could be explained by the fact that $N$. huautlense was also found to be a PGPR microbe that could reduce the accumulation of Cd by plant (Chen et al., 2016). In addition, a horizontal gene transfer could help further explain this phenomenon. It may be conjectured that the functional gene nifH of Rhizobium huautlense was accidentally obtained by YH1 due to close coexistence of the both species in the same region, as was proposed by other researchers before (Andrews et al., 2018).

\section{Pot Culture Experiment in Tailings}

Studies on the in-situ remediation of V-Ti tailings-polluted sites by the association of natively grown L. leucocephala and rhizobia are scarce. Mine tailings in Panzhihua region differ from other mine wastes due to their excessive amounts of extractable iron, titanium, and vanadium among other toxic metals.

L. leucocephala is not deemed as a hyper-accumulator as both biological concentration and translocation factors for most metals of interest were no more than 1.0. In spite of the higher concentrations of $\mathrm{Fe}$ and $\mathrm{Ti}$ in the tailings, the plants did not tend to absorb them as much as $\mathrm{Cu}$ and $\mathrm{Ni}$, which are considered toxic to the plant at a lower dose. Phytoremediation of soils using legume-rhizobia associations can be generalized under two categories: mobilization, being the enhancement of metal uptake by the plants, owing to the production of various mobilizing agents such as biosurfactants, organic acids, siderophores and through biomethylation and redox effects (Ullah et al., 2015); immobilization or stabilization, the process in which the bioavailability of heavy metals in the rhizosphere is reduced due to on-root sorption and precipitation effects by root exudates and microbial metabolites (Salt et al., 1995; Wong, 2003). In this study, it may be concluded that L. leucocephalaYH1 symbiotic system, which led to $8.4 \%$ reduction of plant uptake for $\mathrm{Mn}$ and $65.5 \%$ for $\mathrm{Cd}$ in tailings, has the best reduction effect on $\mathrm{Cd}$. This is again confirmed by vermiculite pot experiment where higher reduction rates on cadmium ranging from 59.7 to $79.4 \%$ were found. Consequently, the significant reduction $(P<0.05)$ of metal uptake except for $\mathrm{Cd}$, as shown in the inoculated group probably implies the positive effects of the strain $\mathrm{YH} 1$ on the host which exhibit the immobilization feature in the root system.

Among a few leguminous tree species, L. leucocephala is able to tolerate higher concentrations of toxic metals compared to non-legumes and is less likely to succumb to multi-metal contaminated substrates (Chan et al., 1999). In addition, there is evidence showing the predominant status of this tree species in the topsoil of $\mathrm{Pb} / \mathrm{Zn}$ mine tailings and the potential of using it as a phytoremediation tool (Zhang et al., 2001). 
The growth state of plant-YH1 consortium demonstrated that, in contrast to control group, plants infected with strain YH1 showed successful nodulation and that biomass yield, plant height, root lengths and NPK contents were significantly elevated. This is indicative of the effectiveness of this inoculum and suggestive of the normal functioning of the symbiotic genes in it. It is widely reported that a number of PGPRs capable of increasing plant yield and improving soil conditions can be used in phytoremediation: these include Achromobacter, Acinetobacter, Actinobacteria, Azotobacter, Bacillus, Flavobacterium, Ochrobactrum, Pseudomonas, Rhizobium, and Bradyrhizobium (Reichman, 2007; Wani et al., 2008; Khan et al., 2009). For a long time, arbuscular mycorrhizal fungi (AMF) have been especially noted for improving phytoremediation by attenuating various metal stresses to the host apart from improving plant growth, whose mechanisms are frequently alluded to those of bacterial PGP strains (Lins et al., 2006). Discoveries of phytostabilization using rhizobia-legume systems came under notice when a number of rhizobial strains were reported to be both PGP-positive and capable of reducing metal uptake for the host. In a separate study, Bradyrhizobium sp. (vigna) RM8, isolated from green gram in metal contaminated sites, tolerant to high levels of nickel and zinc, active in promoting plant growth, was found to be able to cut nickel and zinc intake by the host while alleviating the toxic stresses (Wani et al., 2007). Another instance of phyto-immobilization was recorded by Dary et al. (2010), in which, an effective nitrogen fixer Bradyrhizobium sp. 750 reduced the accumulation of $\mathrm{Cd}, \mathrm{Cu}$, and $\mathrm{Pb}$ by Lupinus luteus in a field experiment on a multi-metal polluted site. There appears to be more metal enhancers than reducers and the former are often coupled with the ability of siderophore production (Glick, 2010), which may be attributed to the fact that siderophores as chelating agents make insoluble metal compounds bioavailable and thereby facilitating metal uptake. However, it works both ways, as established by Dimkpa et al. (2008), in which the accumulation of nickel in cowpea plants was lowered with the help of Ni-binding hydroxamate siderophores produced by Streptomyces acidiscabies, and this may prove that siderophores play a dual role in determining the uptake pattern regarding their various types while other more dominant factors may also have to be taken into account (Ma et al., 2011).

Phosphorus solubilization is another indispensable trait for soil microbes in the immobilization of heavy metals. Free metal ions can be readily precipitated as metal-P complexes of various mineral phases such, taking cadmium as an example, as $\mathrm{Cd}_{5} \mathrm{H}_{2}\left(\mathrm{PO}_{4}\right)_{4} \cdot 4 \mathrm{H}_{2} \mathrm{O}, \mathrm{Cd}\left(\mathrm{H}_{2} \mathrm{PO}_{4}\right)_{2}, \mathrm{Cd}_{3}\left(\mathrm{PO}_{4}\right)_{2}$ and amorphous cadmium phosphates at higher $\mathrm{pH}$ values (Sharma and Archana, 2016), which can be deposited on the surfaces of both roots and microbes in the rhizosphere resulting in reduced metal bioavailability and a reduction in both biological concentration and translocation effects (Park et al., 2011).

Indole-3-acetic acid is a phytohormone which has been widely regarded as an index for assessing the effectiveness of the promotion of cell elongation in plant tissues (Nadeem et al., 2015). The production of IAA by strain YH1 is higher ( $>100$ $\mu \mathrm{g} \mathrm{m}^{-1}$ ) than most rhizobial stains previously reported and can be considered as an IAA-overproducer (Chiboub et al., 2016; Yu et al., 2017). It is observed that negative impact of metal accumulation inside plant tissues could be mitigated by the application of IAA (Nadeem et al., 2015). In our study of microbial phosphorus solubilization, strain $\mathrm{YH} 1$ was found to be more competent than most strains isolated from infertile and polluted soils, which among other PGP traits, further confirmed the effectiveness of strain YH1 to be potentially utilized in the phytoremediation of heavy metal contaminated soils.

As of today, there is limited information on the remediation of soils involving members from Sinorhizobium. It was revealed that some strains of Sinorhizobium meliloti helped with the uptake of $\mathrm{Cd}, \mathrm{Cu}$ and $\mathrm{Zn}$ by Medicago plants with high translocation effects (Fan et al., 2011; Ghnaya et al., 2015; Zribi et al., 2015). Most interestingly, it was found that a symbiotic PGPR strain may help increase the uptake by one plant species while cause the decrease by another, as in the case of Bradyrhizobium sp. YL-6, where it boosted Cd uptake by Lolium multiflorum while reduced Cd uptake by Glycine max (Guo and Chi, 2013).

\section{Pot Culture in Cd/Mn Soils}

Our work exhibited that the plants achieved greater biomass yield in both $\mathrm{Cd}$ and $\mathrm{Mn}$ tainted soils. In this experiment, the cross influence of other metals was minimized by using single metal-spiked vermiculite as substrate. Treatments with YH1 inoculum were all indicative of the successful formation of synergism with the microbe. By comparing plant dry weight between different treatments and the tolerance of $\mathrm{YH} 1$ to $\mathrm{Cd}$ and $\mathrm{Mn}$, it is obvious that $\mathrm{Cd}$ appears to exercise more negative effects on both plant and rhizobia, and this may be explained by the fact that Cd has both higher microbial toxicity and phytotoxicity than Mn (Lambers et al., 2015; Ullah et al., 2015) and that Mn content is way higher in the tailings from which this strain was isolated. Biomass yield and growth parameters of leucaena plants were both reduced under the stress of cadmium even at a low concentration of $25 \mathrm{ppm}$ as revealed by a previous study (Shafiq et al., 2010). Both Cd and Mn can stunt root growth and have damaging effects to leaves (Khan et al., 2011).It has been well explained that, several sophisticated microbial mechanisms conspire to curb the metal bioavailability to plants, which include biosorption onto the outer wall, intracellular sequestration, and complexation by certain biogenic anions (Gadd, 2004).

Root is where the toxic metals exert direct influence on the plant. Changes in this microbial-rhizospheric niche may alter the composition and patterns of exudation, which can further lead to damage to the root-hair cells. The significant increase in root length against the increasing amount of $\mathrm{Cd}$, is probably attributed to the reduced metal stress caused by the immobilization effects.

There existed a great difference regarding the overall uptake of these two separately added metals, in which Mn uptake was more than three times the amounts of $\mathrm{Cd}$ in both groups and the translocation for $\mathrm{Mn}$ was more than 10 times that for $\mathrm{Cd}$. Manganese exhibits extreme toxicity to plant cells in excessive amounts (>500 mg kg-1 in content) and is positively linked to soil acidity and a lack of other exchangeable metal ions such as $\mathrm{Ca}, \mathrm{Mg}$, and Fe in the rhizosphere (de Varennes et al., 2001). The reduction of Mn uptake by plants can be more complicated 
as common microorganisms are usually not directly involved in this process except for manganese oxidizing bacteria, which can increase $\mathrm{Mn}$ availability through the release of low weight bacteriogenic acids as IAA (Millaleo et al., 2010). Therefore, it may be conjectured that Mn resistant strain YH1 helped alleviate manganese uptake through indirect mechanisms by altering the plant exudation patterns, as suggested in studies on AMF-plant interactions (Nogueira and Cardoso, 2003), where plant exudates were changed under the influence of microbial activities resulting in an immobilization effect and reduced metal uptake by the plant.

Cadmium is a toxic metal with high mobility in both plant tissues and soils, the uptake of it by plants is in rise with the increase of its background concentration in both inoculated group and control. It is apparent that in metal-spiked soil, the uptake of $\mathrm{Cd}$ is also drastically reduced with the inoculation of YH1 especially under higher contents, and the plant translocation factor for Cd was also decreased with the inoculation of $\mathrm{YH} 1$, which is consistent with the tailings experiment and further indicates the metal-immobilizing effects on the legume.

\section{Nodulation Under Cd or Mn Stress}

The decreasing trend in nodule yield under both metal stresses against the increasing levels of soil metal contents from 5 to $20 \mathrm{mg} \mathrm{kg}^{-1}$ was reversed in the treatment with $35 \mathrm{mg} \mathrm{kg}^{-1} \mathrm{Mn}$, which may be accounted for by the fact that manganese is less toxic to plants and its microbial symbionts. Manganese is an indispensable trace element constituting the reactive centers of various enzymes and is more than 20 times the amounts of the other metal pollutants in the V-Ti tailings. It should be noted that excessive ingestion of $\mathrm{Mn}$ can also cause toxicity to both plants and bacteria (Zornoza et al., 2010). Investigations by predecessors discovered that although $\mathrm{Mn}$ exists in plants in fairly large amounts, its toxicity can still affect the bacterial growth and legume-rhizobia associations (de Varennes et al., 2001; Hayes et al., 2012). However, our results confirmed that Cd appears to be more toxic than $\mathrm{Mn}$, since the nodule number was lower than in plants treated with $\mathrm{Mn}$ at the same amounts of 5 and $35 \mathrm{mg} \mathrm{kg}^{-1}$.

\section{CONCLUSIONS}

In conclusion, metalliferous $\mathrm{V}$ - $\mathrm{Ti}$ magnetite tailings from Panzhihua region harbor a PGP-positive rhizobia species, which

\section{REFERENCES}

Andrews, M., De Meyer, S., James, E. K., Stepkowski, T., Hodge, S., Simon, M. F., et al. (2018). Horizontal transfer of symbiosis genes within and between rhizobial genera: occurrence and Importance. Genes 9:321. doi: $10.3390 /$ genes 9070321

Ardley, J. (2017). Legumes of the Thar desert and their nitrogen fixing Ensifer symbionts. Plant. Soil. 410, 517-520. doi: 10.1007/s11104-0163125-5

Bashan, Y., and Holguin, G. (1998). Proposal for the division of plant growthpromoting rhizobacteria into two classifications: biocontrol-PGPB (plant was identified as Sinorhizobium saheli YH1. This strain exhibited IAA-producing and phosphate-solubilizing activities and was tolerant to high amounts of $\mathrm{Cd}$ and $\mathrm{Mn}$. It also improved plant height, root length, and biomass yield for L. Leucocephala grown in both $\mathrm{V}$-Ti tailings and soils amended with $\mathrm{Cd} / \mathrm{Mn}$. In particular, strain $\mathrm{YH} 1$ demonstrated abilities to nodulate the plant and reduce the uptake of heavy metals for the plant in the tailings and Cd- / Mn-supplemented soils. Our results thus provide further understanding of the efficiency of $S$. saheli YH1 in promoting plant health under heavy metal-ridden soil environments and suggest that it could be potentially used as an inoculum for the phytoremediation of metal-contaminated soils.

\section{AUTHOR CONTRIBUTIONS}

$\mathrm{XK}$ and $\mathrm{XY}$ conceived the idea and carried out the experimentation. YZ, YL, QC, QW, and WT provided the funding. YC, YG, KZ, QX, and MM supervised the project. LZ, $\mathrm{XZ}$, and LH analyzed the data. JK offered language polishing and editing service.

\section{FUNDING}

This research was financially supported by the Key Research Project (No. 2017SZ0183, No. 2017SZ0087), the Major Science Technology Project (2017NZDZX0003) of Sichuan Province, the Science and Technology Innovation Talent Project of Sichuan Province (No. 2017RZ0064), and the Student Innovation Training Program of Sichuan Agricultural University (No. 201710626072).

\section{ACKNOWLEDGMENTS}

XK gratefully acknowledges receipt of a joint $\mathrm{PhD}$ scholarship from School of Life Sciences, University of Dundee and China Scholarship Council (No. 201606910077).

\section{SUPPLEMENTARY MATERIAL}

The Supplementary Material for this article can be found online at: https://www.frontiersin.org/articles/10.3389/fmicb. 2018.01853/full\#supplementary-material 
from Sulla coronaria resistant to cadmium and to other heavy metals. CR. Biol. 339, 391-398. doi: 10.1016/j.crvi.2016.04.015

Dary, M., Chamber-Pérez, M. A., Palomares, A. J., and Pajuelo, E. (2010). "In situ" phytostabilisation of heavy metal polluted soils using Lupinus luteus inoculated with metal resistant plant-growth promoting rhizobacteria. J. Hazard. Mater. 177, 323-330. doi: 10.1016/j.jhazmat.2009

Datta, C., and Basu, P. (2000). Indole acetic acid production by a Rhizobium species from root nodules of a leguminous shrub, Cajanus cajan. Microbiol. Res. 155, 123-127. doi: 10.1016/S0944-5013(00)80047-6

de Varennes, A., Carneiro, J. P., and Goss, M. J. (2001). Characterization of manganese toxicity in two species of annual medics. J. Plant. Nutr. 24, 1947-1955. doi: 10.1081/PLN-100107606

Dimkpa, C., Svatoš, A., Merten, D., Büchel, G., and Kothe, E. (2008). Hydroxamate siderophores produced by Streptomyces acidiscabies E13 bind nickel and promote growth in cowpea (Vigna unguiculata L.) under nickel stress. Can. J. Microbiol. 54, 163-172. doi: 10.1139/W07-130

Doty, S. L., Shang, T. Q., Wilson, A. M., Moore, A. L., Newman, L. A., Strand, S. E., et al. (2003). Metabolism of the soil and groundwater contaminants, ethylene dibromide and trichloroethylene, by the tropical leguminous tree, Leuceana leucocephala. Water. Res. 37, 441-449. doi: 10.1016/S0043-1354(02)00291-9

Fan, L. M., Ma, Z. Q., Liang, J. Q., Li, H. F., Wang, E. T., and Wei, G. H. (2011). Characterization of a copper-resistant symbiotic bacterium isolated from Medicago lupulina growing in mine tailings. Bioresource. Technol. 102, 703-709. doi: 10.1016/j.biortech.2010.08.046

Gadd, G. M. (2004). Microbial influence on metal mobility and application for bioremediation. Geoderma 122, 109-119. doi: 10.1016/j.geoderma.2004.01.002

Gaunt, M. W., Turner, S. L., Rigottier-Gois, L., Lloyd-Macgilp, S. A., and Young, J. P. (2001). Phylogenies of atpD and recA support the small subunit rRNA-based classification of rhizobia. Int. J. Syst. Evol. Micr. 51, 2037-2048. doi: 10.1099/00207713-51-6-2037

Ghnaya, T., Mnassri, M., Ghabriche, R., Wali, M., Poschenrieder, C., Lutts, S., et al. (2015). Nodulation by Sinorhizobium meliloti originated from a mining soil alleviates Cd toxicity and increases Cd-phytoextraction in Medicago sativa L. Front. Plant Sci. 6:863. doi: 10.3389/fpls.2015.00863

Glick, B. R. (2010). Using soil bacteria to facilitate phytoremediation. Biotechnol. Adv. 28, 367-374. doi: 10.1016/j.biotechadv.2010.02.001

Guo, J., and Chi, J. (2013). Effect of Cd-tolerant plant growth-promoting rhizobium on plant growth and Cd uptake by Lolium multiflorum Lam. and Glycine $\max ($ L.) Merr. in Cd-contaminated soil. Plant Soil 375, 205-214. doi: 10.1007/s11104-013-1952-1

Hayat, R., Ali, S., Amara, U., Khalid, R., and Ahmed, I. (2010). Soil beneficial bacteria and their role in plant growth promotion: a review. Ann. Microbiol. 60, 579-598. doi: 10.1007/s13213-010-0117-1

Hayes, R. C., Conyers, M. K., Li, G. D., Poile, G. J., Price, A., McVittie, B. J., et al. (2012). Spatial and temporal variation in soil $\mathrm{Mn}^{2+}$ concentrations and the impact of manganese toxicity on lucerne and subterranean clover seedlings. Crop. Pasture. Sci. 63, 875-885. doi: 10.1071/CP12138

Khan, M. S., Zaidi, A., Goel, R., and Musarrat, J. editors (2011). Biomanagement of Metal-Contaminated Soils. Vol. 20, Environmental pollution (Dordrecht: Springer).

Khan, M. S., Zaidi, A., Wani, P. A., and Oves, M. (2009). Role of plant growth promoting rhizobacteria in the remediation of metal contaminated soils. Environ. Chem. Lett. 7, 1-19. doi: 10.1007/s10311-008-0155-0

Kimura, M. (1980). A simple method for estimating evolutionary rates of base substitutions through comparative studies of nucleotide sequences. J. Mol. Evol. 16, 111-120. doi: 10.1007/BF01731581

Kong, Z., Mohamad, O. A., Deng, Z., Liu, X., Glick, B. R., and Wei, G. (2015). Rhizobial symbiosis effect on the growth, metal uptake, and antioxidant responses of Medicago lupulina under copper stress. Environ. Sci. Pollut. Res. Int. 22, 12479-12489. doi: 10.1007/s11356-015-4530-7

Laguerre, G., Nour, S. M., Macheret, V., Sanjuan, J., Drouin, P., and Amarger, N. (2001). Classification of rhizobia based on nodC and nifH gene analysis reveals a close phylogenetic relationship among Phaseolus vulgaris symbionts. Microbiology 147, 981-993. doi: 10.1099/00221287-1474-981

Lambers, H., Hayes, P. E., Laliberté, E., Oliveira, R. S., and Turner, B. L. (2015). Leaf manganese accumulation and phosphorus-acquisition efficiency. Trends Plant Sci. 20, 83-90. doi: 10.1016/j.tplants.2014.10.007
Li, M. (2006). Ecological restoration of mineland with particular reference to the metalliferous mine wasteland in China: a review of research and practice. Sci. Total Environ. 357, 38-53. doi: 10.1016/j.scitotenv.2005. 05.003

Li, P., Qian, H., Howard, K. W. F., Wu, J., and Lyu, X. (2014). Anthropogenic pollution and variability of manganese in alluvial sediments of the Yellow River, Ningxia, northwest China. Environ. Monit. Assess. 186, 1385-1398. doi: 10.1007/s10661-013-3461-3

Lins, C. E. L., Cavalcante, U. M. T., Sampaio, E. V. S. B., Messias, A. S., and Maia, L. C. (2006). Growth of mycorrhized seedlings of Leucaena leucocephala (Lam.) de Wit. in a copper contaminated soil. Appl. Soil Ecol. 31, 181-185. doi: 10.1016/j.apsoil.2005.06.004

Liu, G., Tao, L., Liu, X., Hou, J., Wang, A., and Li, R. (2013). Heavy metal speciation and pollution of agricultural soils along Jishui River in non-ferrous metal mine area in Jiangxi Province, China. J. Geochem. Explor. 132, 156-163. doi: 10.1016/j.gexplo.2013.06.017

Ma, Y., Prasad, M. N. V., Rajkumar, M., and Freitas, H. (2011). Plant growth promoting rhizobacteria and endophytes accelerate phytoremediation of metalliferous soils. Biotechnol. Adv. 29, 248-258. doi: 10.1016/j.biotechadv.2010.12.001

Millaleo, R., Reyes-Diaz, M., Ivanov, A. G., Mora, M. L., and Alberdi, M. (2010). Manganese as essential and toxic element for plants: transport, accumulation and resistance mechanisms. J. Soil Sci. Plant Nut. 10, 470-481. doi: 10.4067/S0718-95162010000200008

Nadeem, S. M., Naveed, M., Ahmad, M., and Zahir, Z. A. (2015). "Rhizosphere bacteria for crop production and improvement of stress tolerance: mechanisms of action, applications, and future prospects," in Plant Microbes Symbiosis: Applied Facets, ed N. Arora (Berlin:Springer), 1-36.

Nautiyal, C. S. (1999). An efficient microbiological growth medium for screening phosphate solubilizing microorganisms. FEMS Microbiol. Lett. 170, 265-270. doi: 10.1111/j.1574-6968.1999.tb13383.x

Nogueira, M. A., and Cardoso, E. J. B. N. (2003). Mycorrhizal effectiveness and manganese toxicity in soybean as affected by soil type and endophyte. Sci. Agr. 60, 329-335. doi: 10.1590/S0103-90162003000200018

Novozamsky, R.E., Schonwenburg, J., and Walling, I. (1974). Nitrogen determination in plant material by means of indophenol blue method. Neth. J. Agric. Sci. 22, 3-5.

Pansu, M., and Gautheyrou, J. (2007). Handbook of Soil Analysis: Mineralogical, Organic and Inorganic Methods. Berlin: Springer.

Park, J. H., Bolan, N., Megharaj, M., and Naidu, R. (2011). Isolation of phosphate solubilizing bacteria and their potential for lead immobilization in soil. J. Hazard Mater. 185, 829-836. doi: 10.1016/j.jhazmat.2010.09.095

Rajkumar, M., Ae, N., and Freitas, H. (2009). Endophytic bacteria and their potential to enhance heavy metal phytoextraction. Chemosphere 77, 153-160. doi: 10.1016/j.chemosphere.2009.06.047

Rajkumar, M., Ae, N., Prasad, M. N. V., and Freitas, H. (2010). Potential of siderophore-producing bacteria for improving heavy metal phytoextraction. Trends Biotechnol. 28, 142-149. doi: 10.1016/j.tibtech.2009. 12.002

Reichman, S. (2007). The potential use of the legume-rhizobium symbiosis for the remediation of arsenic contaminated sites. Soil Biol. Biochem. 39, 2587-2593. doi: 10.1016/j.soilbio.2007.04.030

Salt, D. E., Blaylock, M., Kumar, N. P. B. A., Dushenkov, V., Ensley, B. D., Chet, I., et al. (1995). Phytoremediation: a novel strategy for the removal of toxic metals from the environment using plants. Nat. Biotech. 13, 468-474. doi: $10.1038 /$ nbt0595-468

Sanginga, N., Mulongoy, K., and Ayanaba, A. (1988). Nitrogen contribution of Leucaena/Rhizobium symbiosis to soil and a subsequent maize crop. Plant Soil 112, 137-141. doi: 10.1007/BF02181763

Schwyn, B., and Neilands, J. B. (1987). Universal chemical assay for the detection and determination of siderophores. Anal. Biochem. 160, 47-56. doi: 10.1016/0003-2697(87)90612-9

Shafiq, M., Iqbal, M. Z., and Mohammad, A. (2010). Effect of lead and cadmium on germination and seedling growth of Leucaena leucocephala. J. Appl. Sci. Environ. Manage. 12, 61-66. doi: 10.4314/jasem.v12i3.55497

Sharma, R. K., and Archana, G. (2016). Cadmium minimization in food crops by cadmium resistant plant growth promoting rhizobacteria. Appl. Soil Ecol. 107, 66-78. doi: 10.1016/j.apsoil.2016.05.009 
Shelton, H. M., and Brewbaker, J. L. (1998). "Leucaena leucocephala-the most widely used forage tree legume," in Forage Tree Legumes in Tropical Agriculture, eds R C Gutteridge and H M Shelton (Wallingford: CAB International), 15-29.

Somasegaran, P., and Hoben, H. J. (2012). Handbook for Rhizobia: Methods in Legume-Rhizobium Technology. (Germany:Springer).

Tak, N., Awasthi, E., Bissa, G., Meghwal, R. R., James, E. K., Sprent, J. S., et al. (2016). Multi locus sequence analysis and symbiotic characterization of novel Ensifer strains nodulating Tephrosia spp. in the Indian Thar Desert. Syst. Appl, Microbiol. 39, 534-545. doi: 10.1016/j.syapm.2016.08.002

Tamura, K., Stecher, G., Peterson, D., Filipski, A., and Kumar, S. (2013). MEGA6: molecular evolutionary genetics analysis version 6.0. Mol. Biol. Evol. 30, 2725-2729. doi: 10.1093/molbev/mst197

Tan, Z. Y., Xu, X. D., Wang, E. T., Gao, J. L., Martinez-Romero, E., and Chen, W. X. (1997). Phylogenetic and genetic relationships of Mesorhizobium tianshanense and related rhizobia. Int. J. Syst. Bacteriol. 47, 874-879. doi: 10.1099/00207713-47-3-874

Ullah, A., Heng, S., Munis, M. F. H., Fahad, S., and Yang, X. (2015). Phytoremediation of heavy metals assisted by plant growth promoting (PGP) bacteria: a review. Environ. Exp. Bot. 117, 28-40. doi: 10.1016/j.envexpbot.2015.05.001

Vinuesa, P., Rojas-Jiménez, K., Contreras-Moreira, B., Mahna, S. K., Prasad, B. N., Moe, H., et al. (2008). Multilocus sequence analysis for assessment of the biogeography and evolutionary genetics of four Bradyrhizobium species that nodulate soybeans on the Asiatic continent. Appl. Environ. Microb. 74, 6987-6996. doi: 10.1128/AEM.00875-08

Vinuesa, P., Silva, C., Werner, D., and Martínez-Romero, E. (2005). Population genetics and phylogenetic inference in bacterial molecular systematics: the roles of migration and recombination in Bradyrhizobium species cohesion and delineation. Mol. Phylogenet. Evol. 34, 29-54. doi: 10.1016/j.ympev.2004.08.020

Walker, D. J., Rafael Clemente, R., and Bernal, M. P. (2004). Contrasting effects of manure and compost on soil $\mathrm{pH}$, heavy metal availability and growth of Chenopodium album L. in a soil contaminated by pyritic mine waste. Chemosphere 57, 215-224. doi: 10.1016/j.chemosphere.2004.05.020

Wang, F. Q., Wang, E. T., Zhang, Y. F., and Chen, W. X. (2006). Characterization of rhizobia isolated from Albizia spp. in comparison with microsymbionts of Acacia spp. and Leucaena leucocephala grown in China. Syst. Appl. Microbiol. 29, 502-517. doi: 10.1016/j.syapm.2005.12.010

Wani, P. A., Khan, M. S., and Zaidi, A. (2007). Effect of metal tolerant plant growth promoting Bradyrhizobium sp. (vigna) on growth, symbiosis, seed yield and metal uptake by greengram plants. Chemosphere 70, 36-45. doi: 10.1016/j.chemosphere.2007.07.028

Wani, P. A., Khan, M. S., and Zaidi, A. (2008). Effect of metal-tolerant plant growth-promoting Rhizobium on the performance of pea grown in metal-amended soil. Arch. Environ. Con. Tox. 55, 33-42. doi: 10.1007/s00244-007-9097-y

Wong, M. H. (2003). Ecological restoration of mine degraded soils, with emphasis on metal contaminated soils. Chemosphere 50, 775-780. doi: 10.1016/S0045-6535(02)00232-1

Wuana, R. A., and Okieimen, F. E. (2011). Heavy metals in contaminated soils: a review of sources, chemistry, risks and best available strategies for remediation. ISRN Ecol. 2011, 1-20. doi: 10.5402/2011/402647
Xu, K. W., Penttinen, P., Chen, Y. X., Chen, Q., and Zhang, X. (2013a). Symbiotic efficiency and phylogeny of the rhizobia isolated from Leucaena leucocephala in arid-hot river valley area in Panxi, Sichuan, China. Appl. Microbiol. Biot. 97, 783-793. doi: 10.1007/s00253-012-4246-2

Xu, K. W., Penttinen, P., Chen, Y. X., Zou, L., Zhou, T., Zhang, X., et al. (2013b). Polyphasic characterization of rhizobia isolated from Leucaena leucocephala from Panxi, China. World J. Microb. Biot. 29, 2303-2315. doi: 10.1007/s11274-013-1396-Z

Yu, X., Li, Y., Cui, Y., Liu, R., Li, Y., Chen, Q., et al. (2017). An indoleacetic acid producing Ochrobactrum sp. MGJ11 counteracts cadmium effect on soybean by promoting plant growth. J. Appl. Microbiol. 122, 987-996. doi: 10.1111/jam.13379

Yu, X., Li, Y., Li, Y., Xu, C., Cui, Y., Xiang, Q., et al. (2016). Pongamia pinnata inoculated with Bradyrhizobium liaoningense PZHK1 shows potential for phytoremediation of mine tailings. Appl. Microbiol. Biot. 101, 1739-1751. doi: 10.1007/s00253-016-7996-4

Yu, X., Li, Y., Zhang, C., Liu, H., Liu, J., Zheng, W., et al. (2014). Culturable heavy metal-resistant and plant growth promoting bacteria in $\mathrm{V}$ Ti magnetite mine tailing soil from Panzhihua, China. PloS ONE 9:e106618. doi: 10.1371/journal.pone.0106618

Zhang, Y., Kang, X., Liu, H., Liu, Y., Li, Y., Yu, X., et al. (2018). Endophytes isolated from ginger rhizome exhibit growth promoting potential for Zea mays. Arch. Agron. Soil. Sci. 64, 1302-1314. doi: 10.1080/03650340.2018.1430892

Zhang, Z., Shu, W., Lan, C., and Wong, M. (2001). Soil seed bank as an input of seed source in revegetation of lead/zinc mine tailings. Restor. Ecol. 9, 378-385. doi: 10.1046/j.1526-100X.2001.94007.x

Zheng, T., Yang, J., Huang, P., Tang, C., and Wan, J. (2018). Comparison of trace element pollution, sequential extraction, and risk level in different depths of tailings with different accumulation age from a rare earth mine in Jiangxi Province, China. J. Soil. Sediment. 18, 992-1002. doi: 10.1007/s11368-017-1853-7

Zornoza, P., Sánchez-Pardo, B., and Carpena, R. O. (2010). Interaction and accumulation of manganese and cadmium in the manganese accumulator Lupinus albus. J. Plant. Physiol. 167, 1027-1032. doi: 10.1016/j.jplph.2010.02.011

Zribi, K., Nouairi, I., Slama, I., Talbi-Zribi, O., and Mhadhbi, H. (2015). Medicago sativa-Sinorhizobium meliloti symbiosis promotes the bioaccumulation of zinc in nodulated roots. Int. J. Phytoremediat. 17, 49-55. doi: 10.1080/15226514.2013.828017

Conflict of Interest Statement: The authors declare that the research was conducted in the absence of any commercial or financial relationships that could be construed as a potential conflict of interest.

Copyright (C) 2018 Kang, Yu, Zhang, Cui, Tu, Wang, Li, Hu, Gu, Zhao, Xiang, Chen, $\mathrm{Ma}$, Zou, Zhang and Kang. This is an open-access article distributed under the terms of the Creative Commons Attribution License (CC BY). The use, distribution or reproduction in other forums is permitted, provided the original author(s) and the copyright owner(s) are credited and that the original publication in this journal is cited, in accordance with accepted academic practice. No use, distribution or reproduction is permitted which does not comply with these terms. 